\title{
Carbon storage and its changes in Chinese terrestrial ecosystem in recent decades
}

\author{
Lixia Wang ${ }^{1}$, Changxin Zou ${ }^{1,2 *}$, Yan Wang ${ }^{1}$, Naifeng Lin ${ }^{1}$ \\ ${ }^{1}$ Nanjing Institute of Environmental Science,Ministry of Ecology and Environment of the People's Republic of China, Nanjing \\ 210042, China \\ ${ }^{2}$ Jiangsu Collaborative Innovation Center of Atmospheric Environment and Equipment Technology(CICAEET),Nanjing University of \\ Information Science \& Technology, Nanjing 210044, China
}

\begin{abstract}
This paper made a comprehensive assessment on carbon storage in terrestrial ecosystem in China by reviewing published literatures. Much more detailed carbon storages in vegetation, soil and ecosystem were summarized for forest, grassland, shrub, cropland and wetland in recent decades. It was discovered that total terrestrial carbon storage in China was 67.9 191.8 Pg C in recent decades, $6.1 \sim 57.57$ $\mathrm{Pg} \mathrm{C}$ was stored in vegetation, and $161.7 \sim 185.7 \mathrm{Pg} \mathrm{C}$ was stored in topsoil at a depth of $100 \mathrm{~cm}$. Vegetation carbon storage has increased obviously in recent years; soil carbon storage declined in some areas owing to intensive land use, while it increased in other areas because of fertilizer application and reforestation. Total terrestrial carbon storage over China has increased in recent decades, and it is expected to

continue

to

increase.
\end{abstract}

\section{Introduction}

Carbon in terrestrial ecosystems exists mainly in vegetation and soil in the form of organic or inorganic carbon[1]. Terrestrial carbon storage dynamics has attracted attention in recent years because it contributes to essential information about carbon budgets, which is important in predicting climate change. Several previous studies provided various estimates of terrestrial carbon storage across China[2-3]. However, different methods usually resulted in different estimates of carbon storage[4-7]. There exists uncertainty of the estimated terrestrial carbon storage because of climate change and anthropogenic activities altered biogeochemical cycles[8-9].

To obtain a comprehensive insight for terrestrial carbon storage in China, this paper will assess Chinese terrestrial carbon storage (including vegetation carbon and soil carbon) and its change trend. Much more detailed vegetation and soil carbon storage will be summarized for forest, grassland, cropland and wetland ecosystems by published literature. Uncertain estimates from data sources, methodology and unstable environments were discussed.

\section{Methods}

Vegetation carbon storage, soil carbon storage and terrestrial carbon storage in China were investigated by published literatures respectively. Terrestrial carbon is stored mainly in forest, grassland, shrub, farmland and wetland ecosystems. The detailed carbon storage in vegetation, soil and total terrestrial ecosystem were examined for forest, shrub, grassland, cropland and wetland ecosystems.

To explore the change of vegetation carbon storage, the average carbon storage was calculated for each specific period (1973-1976, 1977-1981, 1984-1988, 1989-1993, 1994-1998,1999-2003, 2004-2008) of seven national forest inventories. To examine the change of soil carbon storage, soil carbon storage was summarized at different soil depths. The terrestrial carbon storage and its dynamics in different periods was examined for Chinese forest, shrub, grassland, cropland and wetland ecosystems. In the end, the paper discussed the credibility of these estimates of carbon storage

\section{Results}

\subsection{Vegetation carbon storage}

\subsubsection{Vegetation carbon storage in terrestrial ecosystem}

In Mid-Holocene, there was the largest vegetation carbon storage of 70.6 Pg C in China. In recent decades, Chinese vegetation carbon storage was estimated of 6.1 57.9 Pg C according to different estimates methods in the published literature (Table 1).

Although there were disagreement about total vegetation carbon storage, lots of studies confirmed that vegetation carbon storage increased in recent years, since vegetation carbon storage increased in forest, shrub and

\footnotetext{
${ }^{*}$ Corresponding author: zcx@nies.org
} 
farmland ecosystems [13-14]. Carbon from atmosphere was input vegetation systems at a rate of $1.8 \mathrm{Pg} \mathrm{C} / \mathrm{a}$ in China according to the Carnegie-Ames-Stanford Approach (CASA), at a rate of 2.91 3.37 Pg C/a by the Lund-Potsdam-Jena Dynamic Global Vegetation Model (LPJ-DGVM), and at a rate of $3.12 \mathrm{Pg} \mathrm{C} / \mathrm{a}$ by a remote sensing model [15-17]. In short, these studies provided an approximate input rate of $1.8 \sim 3.37 \mathrm{Pg} \mathrm{C} / \mathrm{a}$ in recent decades. However, it is not clear how much carbon in vegetation was released into soil and atmosphere at the same period.

Table 1. Vegetation carbon storage in China

\begin{tabular}{|l|c|l|c|l|}
\hline Period & $\begin{array}{c}\text { Vegetation C } \\
\text { Storage } \\
\text { (Pg C) }\end{array}$ & Method & $\begin{array}{c}\text { Spatial } \\
\text { resolution }\end{array}$ & Reference \\
\hline $\begin{array}{l}\text { Last glacial } \\
\text { maximum }\end{array}$ & 15.5 & $\begin{array}{l}\text { Osnabrück } \\
\text { model }\end{array}$ & $0.5^{\circ}$ & {$[5]$} \\
\hline $\begin{array}{l}\text { Mid- } \\
\text { Holocene }\end{array}$ & 70.6 & $\begin{array}{l}\text { Osnabrück } \\
\text { model }\end{array}$ & $0.5^{\circ}$ & {$[5]$} \\
\hline Present & 57.9 & $\begin{array}{l}\text { Data-based } \\
\text { estimates }\end{array}$ & $0.5^{\circ}$ & {$[5]$} \\
\hline Present & 6.1 & $\begin{array}{l}\text { Biogeograp } \\
\text { hical model }\end{array}$ & - & {$[4]$} \\
\hline $1980 \mathrm{~s}$ & 57.57 & $\begin{array}{l}\text { BIOME3 } \\
\text { model }\end{array}$ & $10^{\prime}$ & {$[10]$} \\
\hline $1980 \mathrm{~s}$ & 35.23 & $\begin{array}{l}\text { BIOME3 } \\
\text { model } \\
\& \text { Baseline } \\
\text { vegetation }\end{array}$ & - & {$[6]$} \\
\hline $1980 \mathrm{~s}$ & 53.96 & $\begin{array}{l}\text { BIOME3 } \\
\text { model } \\
\& \text { Baseline } \\
\text { biome }\end{array}$ & $10^{\prime}$ & {$[6]$} \\
\hline $1981-1998$ & 13.33 & $\begin{array}{l}\text { CEVSA } \\
\text { model }\end{array}$ & $0.5^{\circ}$ & {$[11]$} \\
\hline $1961-1990$ & 14.04 & $\begin{array}{l}\text { AVIM2mod } \\
\text { el }\end{array}$ & $0.1^{\circ}$ & {$[12]$} \\
\hline $2004-2014$ & 14.60 & \begin{tabular}{l} 
Statistics \\
\hline
\end{tabular} & {$[84]$} \\
\hline
\end{tabular}

\subsubsection{Vegetation carbon storage in different ecosystems}

(1) Vegetation carbon storage in forest ecosystem

Vegetation carbon storage in Chinese forest ecosystem increased from $3.26 \mathrm{Pg} \mathrm{C}$ in 1949 to $11.49 \mathrm{Pg}$ $\mathrm{C}$ in 2014, and the growth mainly resulted from forest expansion, for example forest area increased from 95.6 $\mathrm{km}^{2}$ to $195.89 \mathrm{~km}^{2}$ between 1949 and 2014 (Table 2). To explore the detailed change in forest carbon storage, we calculated average forest carbon storage for each period (1973 1976, 1977 1981, 1984 1988, 1989 1993, 1994 1998,1999 2003, 2004 2008) according to the results of seven national forest inventories in previous studies, and confirmed that carbon storage in Chinese forests increased obviously between 1949 and 2014 (Fig.1 \& Table 2).

However, vegetation carbon storage in Chinese forests decreased to the lowest point in the 1970s because of massive disafforestation [18-20]. After the 1970s, forest carbon storage increased rapidly due to reforestation at a rate of $75 \mathrm{Tg} \mathrm{C} / \mathrm{a}$ between 1977 and 2003 , and a rate of $85.3 \sim 101.95 \mathrm{Tg} \mathrm{C} / \mathrm{a}$ between 1989 and $2003[13,21]$. It was forecasted that carbon storage in Chinese forests would increase at a rate of $1649.6 \mathrm{~T} \mathrm{~g}$ C/a between 2000 and 2025 under a policy scenario of returning farmland to forest [22]. Vegetation carbon storage in forest would increase to $10.23 \mathrm{Pg} \mathrm{C}$ in 2050 under continuous natural forest growth [23].

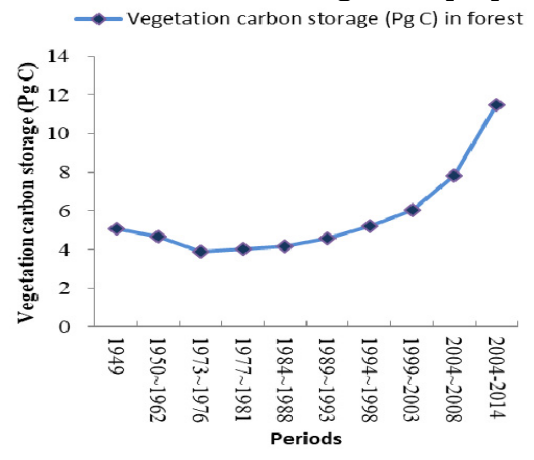

Fig.1. Vegetation carbon storages (average value of previous studies) in Chinese forest at different periods

(2) Vegetation carbon storage in grassland ecosystem

Vegetation carbon storage in Chinese grassland ecosystem was estimated of 1.04 4.66 Pg C by various studies [4,6,21] (Table3). According to national grassland survey in the $1980 \mathrm{~s}$, the highest estimate of vegetation carbon storage in grassland was $4.66 \mathrm{Pg} \mathrm{C}$ [6, 34 , and the lowest estimate of vegetation carbon storage was $1.15 \mathrm{Pg} \mathrm{C}[4,13]$. Vegetation carbon storage in grassland ecosystems did not change significantly, just a slight increase at a rate of $126.67 \mathrm{Tg} \mathrm{C} / \mathrm{a}$ in recent decades [35-37].

(3) Vegetation carbon storage in shrub ecosystem

Vegetation carbon storage in Chinese shrub ecosystem was estimated of $30 \sim 35.34 \mathrm{Pg} \mathrm{C}$ by various studies [6]. Owing to protection and reforestation policy, shrub vegetation carbon increased obviously. The increase rate of net carbon in shrubs between 1981 and 2000 was estimated to be $14 \sim 24 \mathrm{Tg} \mathrm{C} / \mathrm{a}$ by the CASA model [13], and $21.7 \pm 10.2 \mathrm{Tg} \mathrm{C} / \mathrm{a}$ by satellite-based inventory [14].

(4) Vegetation carbon storage in cropland ecosystem

Vegetation carbon storage in cropland usually didn't count into total vegetation carbon storage because of annual harvesting. In fact, annual crops fixed huge carbon from atmosphere. It was discovered that annual crops absorbed $146 \mathrm{Tg} \mathrm{C} / \mathrm{a}, 159 \mathrm{Tg} \mathrm{C} / \mathrm{a}, 260 \mathrm{Tg} \mathrm{C} / \mathrm{a}, 394$ $\mathrm{Tg} \mathrm{C} / \mathrm{a}$, and $513 \mathrm{Tg} \mathrm{C} / \mathrm{a}$ in the 1950s, the 1960s, the 1970 s, the 1980s and the 1990s respectively [40], which showed an increasing crops carbon markedly since the 1950s. Another study suggested vegetation carbon in cropland ecosystems increased at a rate of $12.5 \sim 14.3 \mathrm{Tg}$ $\mathrm{C} / \mathrm{a}$ in the period of 1982-1999 [13], and this increase mainly resulted from fertilizer application [41].

(5) Vegetation carbon storage in wetland ecosystem

There is no report about vegetation carbon storage in wetland at a national scale. However, a study showed that total carbon storage was $8 \sim 10 \mathrm{Pg} \mathrm{C}$ in Chinese wetland in recent years [42], and $15 \%$ of carbon was stored in vegetation in some wetlands [43]. Thus, it can 
be inferred that vegetation carbon storage was 1.2 1.5 $\mathrm{Pg} \mathrm{C}$ in Chinese wetland. It was also reported that vegetation carbon storage in wetland was $0.20 \mathrm{Pg} \mathrm{C}$ in 2004-2014 [84]. Vegetation carbon storage in Chinese wetland decreased significantly because vast areas of wetland disappeared, but it was not clear how much vegetation carbon lost [28, 44].

Table 2. Vegetation carbon storage in Chinese forest ecosystem

\begin{tabular}{|c|c|c|c|c|c|}
\hline Period & Data source & $\begin{array}{c}\text { Forest area } \\
\left(10^{6} \mathrm{ha}\right)\end{array}$ & $\begin{array}{c}\text { Carbon torage } \\
(\mathrm{Pg} \mathrm{C})\end{array}$ & Methods & Reference \\
\hline 1949 & Estimated data & 102.34 & 5.06 & Improved volume biomass method & {$[24]$} \\
\hline $1950 \sim 1962$ & Estimated data & 98.08 & 4.67 & Improved volume biomass method & {$[24]$} \\
\hline 1973-1976 & The 1st investigation & 96.03 & 3.75 & Volume biomass method & [19] \\
\hline $1973-1976$ & The 1st investigation & 101.26 & 4.44 & Improved volume biomass method & {$[24]$} \\
\hline 1973-1976 & The 1st investigation & 105 & 3.51 & Age-base volume biomass method & {$[25]$} \\
\hline 1973-1976 & The 1st investigation & 108.22 & 3.85 & Age-base volume biomass method & {$[26]$} \\
\hline $1977-1981$ & The 2nd investigation & 95.63 & 4.12 & Volume biomass method & [19] \\
\hline 1977-1981 & The 2nd investigation & 95.62 & 4.38 & Improved volume biomass method & {$[24]$} \\
\hline $1977-1981$ & The 2nd investigation & 95.6 & 3.6 & Age-base volume biomass method & {$[25]$} \\
\hline 1977-1981 & The 2nd investigation & 116.5 & 4.3 & Continuous biomass expansion factor method & {$[13]$} \\
\hline $1977-1981$ & The 2nd investigation & 95.62 & 3.7 & Age-base volume to biomass method & {$[26]$} \\
\hline $1984-1988$ & The 3rd investigation & 118.46 & 4.55 & Volume biomass method & {$[27]$} \\
\hline $1985-1988$ & The 3rd investigation & 102.2 & 4.06 & Volume biomass method & {$[19]$} \\
\hline 1984-1988 & The 3rd investigation & 102.19 & 3.26 & Volume derived method & {$[8]$} \\
\hline 1984-1988 & The 3 rd investigation & 102.19 & 3.72 & Age-base volume biomass method & {$[28]$} \\
\hline 1984-1988 & The 3rd investigation & 102.19 & 4.45 & Improved volume biomass method & {$[24]$} \\
\hline $1984-1988$ & The 3rd investigation & 102.2 & 3.69 & Age-base volume biomass method & {$[25]$} \\
\hline 1984-1988 & The 3rd investigation & 102.19 & 3.76 & Age-base volume biomass method & {$[26]$} \\
\hline 1984-1988 & The 3rd investigation & 124.2 & 4.46 & Continuous biomass expansion factor method & [13] \\
\hline $1984-1988$ & The 3rd investigation & 102.19 & 5.71 & Mean biomass density method & {$[29]$} \\
\hline 1984-1988 & The 3rd investigation & 102.19 & 4.02 & Continuous biomass expansion factor method & {$[29]$} \\
\hline 1984-1988 & The 3rd investigation & 102.19 & 4.19 & Mean ratio method & [29] \\
\hline 1989-1993 & The 4th investigation & 108.62 & 6.2 & Volume biomass method & {$[30]$} \\
\hline 1989-1993 & The 4 th investigation & 108.64 & 4.2 & Volume biomass method & [19] \\
\hline $1989-1993$ & The 4 th investigation & 108.63 & 4.63 & Improved volume biomass method & {$[24]$} \\
\hline 1989-1993 & The 4th investigation & 108.6 & 4.02 & Age-base volume biomass method & {$[25]$} \\
\hline 1989-1993 & The 4th investigation & 108.64 & 3.78 & Volume derived method & {$[31]$} \\
\hline 1989-1993 & The 4th investigation & 108.64 & 3.78 & Volume derived method & [32] \\
\hline 1989-1993 & The 4th investigation & 108.64 & 4.11 & Age-base volume biomass method & {$[26]$} \\
\hline 1989-1993 & The 4th investigation & Unknown & 4.22 & Volume biomass method & {$[21]$} \\
\hline 1989-1993 & The 4th investigation & 108.64 & 4.45 & Continuous biomass expansion factor method & {$[29]$} \\
\hline 1989-1993 & The 4th investigation & 108.64 & 6.03 & Mean biomass density method & [29] \\
\hline 1989-1993 & The 4th investigation & 108.64 & 4.71 & Mean ratio method & [29] \\
\hline 1994-1998 & The 5 th investigation & 105.82 & 4.75 & Improved volume biomass method & {$[24]$} \\
\hline 1994-1998 & The 5th investigation & 129.2 & 4.66 & Age-base volume biomass method & {$[26]$} \\
\hline 1994-1998 & The 5 th investigation & Unknown & 4.65 & Volume biomass method & {$[21]$} \\
\hline 1994-1998 & The 5 th investigation & 129.2 & 5.02 & Continuous biomass expansion factor method & {$[29]$} \\
\hline 1994-1998 & The 5 th investigation & 129.2 & 7.11 & Mean biomass density method & {$[29]$} \\
\hline 1994-1998 & The 5th investigation & 129.2 & 5.21 & Mean ratio method & {$[29]$} \\
\hline 1999-2003 & The 6 th investigation & 142.79 & 5.51 & Age-base volume biomass method & {$[26]$} \\
\hline
\end{tabular}




\begin{tabular}{|c|c|c|c|c|}
\hline 1999-2003 & The 6th investigation & Unknown & 5.16 & Volume biomass method \\
\hline 1999-2003 & The 6th investigation & 142.79 & 5.86 & Continuous biomass expansion factor method \\
\hline 1999-2003 & The 6th investigation & 142.79 & 7.73 & Mean biomass density method \\
\hline 1999-2003 & The 6th investigation & 142.79 & 6.21 & Mean ratio method \\
\hline 2004-2008 & The 7th investigation & 195.45 & 7.81 & Biomass regression model \\
\hline 2004-2014 & $\begin{array}{c}\text { Published literature } \\
\text { and investigation data }\end{array}$ & 195.89 & 11.49 & Statistics \\
\hline
\end{tabular}

Table 3. Vegetation carbon storage in Chinese grassland ecosystem

\begin{tabular}{|c|c|c|c|c|c|c|}
\hline Period & $\begin{array}{c}\text { Grassland area } \\
\left.10^{4} \mathrm{~km}^{2}\right)\end{array}$ & $\begin{array}{c}\text { Grassland } \\
\text { classification }\end{array}$ & $\begin{array}{c}\text { Vegetation C } \\
\text { storage(Pg C) }\end{array}$ & Data source & Methods \\
\hline $1980 \mathrm{~s}$ & 569.9 & 8 & 1.23 & land use and an agricultural atlas & Biomass method & {$[4]$} \\
\hline $1980 \mathrm{~s}$ & 405.87 & 11 & 4.66 & vegetation map of China (1982) & Carbon density-area method & {$[6]$} \\
\hline $1981 \sim 1988$ & 298.97 & 18 & 3.06 & National grassland survey & Carbon density-area method & [34] \\
\hline $1981 \sim 1998$ & 263.26 & 2 & 3.35 & Global data of climate, soil and NDVI & CEVSA model & Statistical model \\
\hline $1981 \sim 1988$ & 331.41 & 17 & 1.04 & National grassland survey and remote & [11] \\
\hline $1981 \sim 1988$ & 334.1 & 17 & 1.05 & National grassland survey and remote & Statistical model \\
\hline $1981-1988$ & 331.41 & 17 & 1.15 & National grassland survey & Biomass method \\
\hline $1981-1988$ & 330.995 & 18 & 3.32 & National grassland survey and & [35] \\
\hline $2004-2014$ & 280.44 & 1.94 & Published literature and investigation & Biomass method & Stata \\
\hline
\end{tabular}

\subsection{Soil carbon storage}

\subsubsection{Soil carbon storage in terrestrial ecosystem}

Soil carbon (SOC and SIC) storage in Chinese terrestrial ecosystems was estimated of 161.7 185.7 Pg C at a depth of $100 \mathrm{~cm}$ by a detailed national soil inventory [4, 45]. The maximum soil carbon storage (SOC and SIC) was estimated to be $382.1 \mathrm{Pg} \mathrm{C}$ over the entire soil profile [45].

SOC storage was estimated of $23.8 \sim 27.4 \mathrm{Pg} \mathrm{C}$, 50 185 Pg C and 82.65 147.9 Pg C for vertical soil depths of $0-20 \mathrm{~cm}, 0-100 \mathrm{~cm}$ and $>100 \mathrm{~cm}$ respectively according to different studies (Table 4). For the spatial distribution of SOC, the largest storage of SOC (23.60 $\mathrm{Pg} \mathrm{C}$ ) was seen in Southwest China [46].

SIC storage was estimated to be $77.9 \mathrm{Pg} \mathrm{C}$ at a depth of $100 \mathrm{~cm}$ and $234.2 \mathrm{Pg} \mathrm{C}$ in the entire soil profile according to some studies [45]. An estimate of SIC storage was $53.3 \pm 6.3 \mathrm{Pg} \mathrm{C}$ at a depth of $200 \mathrm{~cm}$, and 60 $\mathrm{Pg} \mathrm{C}$ at a depth of $250 \mathrm{~cm}$ by other studies [47,60].

There were opposing arguments about changes in soil carbon storage. It was discovered that soil carbon storage declined owing to agricultural reclamation beginning in the 1950s in some regions [61-64], which led to a net loss of $2.86 \mathrm{Pg} \mathrm{C}$ in the last 20 years [59]. However, soil carbon storage increased at a rate of 105 198Tg C/a for SOC and 7 138Tg C/a for SIC in recent decades [65]. It was also reported that SOC in farmland increased at a rate of $23.61 \mathrm{Tg} \mathrm{C} / \mathrm{a}$ because of fertilizer application; SOC in forests has increased at a rate of $11.72 \mathrm{Tg} \mathrm{C} / \mathrm{a}$ because of reforestation [59].

\subsubsection{Soil carbon storage in different ecosystems}

(1) Soil carbon storage in forest ecosystem
SOC storage at soil depth of $100 \mathrm{~cm}$ was $15.04 \sim 34.23 \mathrm{Pg} \mathrm{C}$ in forest ecosystem. For different soil depths, SOC in Chinese forests was estimated of $5.2 \mathrm{Pg}$ C, 8.91 Pg C, 10.89 Pg C, 13.04 Pg C and 15.04 Pg C at soil depths of $0-10 \mathrm{~cm}, 0-20 \mathrm{~cm}, 0-30 \mathrm{~cm}, 0-50 \mathrm{~cm}$ and $0-100 \mathrm{~cm}$ respectively in the 1980 s [51]. For average soil depths of $17.3 \mathrm{~cm}, 81.9 \mathrm{~cm}$ and $99.2 \mathrm{~cm}, \mathrm{SOC}$ in Chinese forest was 13.67 Pg C, 20.56 Pg C and 34.23 Pg $\mathrm{C}$ respectively in the 1980s [59]. It was estimated 22.59 $\mathrm{Pg} \mathrm{C}$ for soil depth of $0-100 \mathrm{~cm}$ in 2004-2014 by published literature and investigation data [84]. There was no report about total soil carbon storage (SOC and SIC) in Chinese forests, but total soil carbon storage must be larger than SOC of 15.04 34.23 Pg C.

Soil carbon storage in Chinese forests changed due to the variability in forest area in recent decades. It was reported that soil carbon storage in forest decreased at a rate of $122 \mathrm{Tg} \mathrm{C} / \mathrm{a}$ owing to forest shrinkage during 1950-1987, and then increased at a rate of $176.7 \mathrm{Tg} \mathrm{C} / \mathrm{a}$ owing to forest expansion during 1988-2001[14, 66-67].

(2) Soil carbon storage in shrub ecosystem

Soil carbon storage in Chinese shrub was estimated of 9.1 13.6 Pg C at a depth of $0-100 \mathrm{~cm}$ in recent decades by different studies [50-51, 68, 84]. Likely, soil carbon storage in Chinese shrub has increased since the 1980 s owing to large scale shrub recovery. It was reported that soil in shrub land has become the largest soil carbon sink (39 Tg C/a) among Chinese ecosystems since the 1980s [14].

(3) Soil carbon storage in grassland ecosystem

Soil carbon storage in Chinese grassland was estimated to be $23.75 \sim 74.74 \mathrm{Pg} \mathrm{C}$ by different methods. The highest estimate of soil carbon storage in grassland was up to $74.74 \mathrm{Pg} \mathrm{C}$ by the biomass method [4]. The lowest estimate of soil carbon storage in grassland was 
23.75 Pg C by published literature and investigation data [84]. Carbon storage in Chinese grassland ecosystem remained relatively stable, though some change was seen in regional soil due to disturbance from human and climate over the past 20 years [36-37].

(4) Soil carbon storage in cropland ecosystem

SOC in cropland was 5.1 Pg C in topsoil $(0-30 \mathrm{~cm})$ according to the 2nd national soil survey in 1979-1982, but it was not clear how much SIC in cropland ecosystem [69]. There was a large soil carbon storage of $15.17 \mathrm{Pg} \mathrm{C}$ at soil depth $0-100 \mathrm{~cm}$ in cropland in 20042014 according to published literature and investigation data [84].

There were conflicting arguments about the change of soil carbon storage in cropland. It was reported that approximately $51 \%$ of cropland experienced carbon loss, and there was a loss rate of $15 \mathrm{t} \mathrm{C/ha}$ from 1979 to 1982 , and a loss rate of 73.8 Tg C/a from 1995 to 1998 [64, 69$70]$. On the contrary, it was reported that soil carbon in most croplands $(81 \%)$ increased at a rate of $15 \mathrm{Tg} \mathrm{C} / \mathrm{a}$, $25 \mathrm{Tg} \mathrm{C} / \mathrm{a}$ and $33 \mathrm{Tg} \mathrm{C} / \mathrm{a}$ in the 1980s, the 1990s and the 2000s, respectively [71]. Improved crop management (including practices such as straw return into soil, organic fertilizer application, and reduced tillage practices etc.) contributed to the increase [41].

(5) Soil carbon storage in wetland ecosystem

There lacks of reports about soil carbon storage in Chinese wetlands at a national scale. Nevertheless, there is available information that total carbon storage was around $8 \sim 10 \mathrm{Pg} \mathrm{C}$ in Chinese wetland in recent years [42], and there was a ratio $84.54 \% \sim 99.53 \%$ of soil carbon to total carbon in wetland [43]. It therefore could be inferred that soil carbon storage in Chinese wetland was $6.76 \sim 9.95 \mathrm{Pg} \mathrm{C}$. Another report suggested that there was only 3.41 Pg C in wetland soil in 2004-2014 [84].

Unfortunately, soil carbon storage in wetland decreased greatly due to wetland's shrinkage since the 1950s [28, 44, 72]. For example, $3 \times 10^{4} \mathrm{~km}^{2}$ of marshland in Northeast China has been destroyed, resulting in a loss of 218 240 $\mathrm{Tg} \mathrm{C}$ [73-74]. However, not all wetlands suffered a loss of soil carbon. Soil carbon storage has increased by $101.61 \mathrm{Tg} \mathrm{C}$ in paddy soil, and 129.06 Tg C in fluvo-aquic soil from the $1980 \mathrm{~s}$ to the 2000s owing to an increase in the use of chemical fertilizers [59].

\subsection{Total terrestrial carbon storage}

\subsubsection{Total carbon storage in terrestrial ecosystem}

Total carbon storage in terrestrial ecosystem over China was estimated of $67.9 \sim 191.8 \mathrm{Pg} \mathrm{C}$, with an average terrestrial carbon storage of $158 \mathrm{Pg} \mathrm{C}$ in recent years (Table 5). For ancient historical carbon storage in China, it was estimated only $67.9 \mathrm{Pg} \mathrm{C}(1.55 \mathrm{Pg} \mathrm{C}$ in vegetation and $52.4 \mathrm{Pg} \mathrm{C}$ in soil) by an empirical Osnabrück biosphere model in the last glacial maximum, then increased to $183.4 \mathrm{Pg} \mathrm{C}$ (70.6 Pg C in vegetation and 112.8 Pg C in soil) in the mid-Holocene, then decreased to $157.9 \mathrm{Pg} \mathrm{C}$ (57.9 $\mathrm{Pg} \mathrm{C}$ in vegetation and $100 \mathrm{Pg} \mathrm{C}$ in soil) until the modern period [5]. However, the estimates may not be accurate because these estimations derived from presumptive information on palaeovegetation and palaeoclimate with coarse spatial resolution of $0.5^{\circ} \times 0.5^{\circ}$ grid level [6].

In the present age, total terrestrial carbon storage was estimated $95.98 \mathrm{Pg} \mathrm{C}$ (13.33 $\mathrm{Pg} \mathrm{C}$ in vegetation and $82.65 \mathrm{Pg} \mathrm{C}$ in soil) in China by the CEVSA (Carbon Exchange between Vegetation, Soil and Atmosphere) model [21]. However this model was based on data from a global database with a coarse spatial resolution, so it may not be accurate.

More credible terrestrial carbon storage were available owing to a series of ecological surveys and observational studies on national scale in recent years [68]. The total terrestrial carbon storage over China varied widely by different methods. For example, total terrestrial carbon storage in China was estimated to be 191.8 Pg C (6.1 Pg C in vegetation, and 185.7 Pg C in soil) by field samples of net primary production (NPP) [4], $154.99 \mathrm{Pg} \mathrm{C}$ by the latest climate and baseline vegetation data, 153.43 Pg C, 158.08 Pg C and 158.54 $\mathrm{Pg} \mathrm{C}$ with grid cells of $10^{\prime}, 20^{\prime}$ and $30^{\prime}$ respectively by the Biome model [6]. The lowest estimation in terrestrial carbon storage was 99.15 Pg C (14.60 in vegetation and 84.55 in soil) in 2004-2014 according to published soil organic carbon data [84]. These terrestrial carbon storages might be underestimated, because soil carbon storage below $100 \mathrm{~cm}$ is not calculated usually [75], and vegetation carbon storage in protected farmland forests, bamboo forests and other economical important forests was often ignored [13].

Total terrestrial carbon storage over China has increased obviously in recent decades. The increase in terrestrial carbon storage mainly resulted from the increase in vegetation carbon storage due to fertilizer application and expansion of forest and shrub [13, 21, 41]. The terrestrial ecosystem in China got 1.8 3.37 Pg $\mathrm{C} / \mathrm{a}$ from vegetation photosynthesis $[15,17]$, with a net increasing rate of 96.1 106.1 Tg C/a in recent decades [13-14]. It was forecast that Chinese terrestrial carbon storage would increase 5.09 15.91 $\mathrm{Pg} \mathrm{C}$ in the future under climate scenarios that predict $\mathrm{CO}_{2}$ concentration of 340-500 ppmv [6].

Table 4. Soil organic carbon (SOC) storage in China

\begin{tabular}{|l|l|l|l|l|l|l|l|l|}
\hline Study area & $\begin{array}{l}\text { Soil area } \\
\left(10^{4} \mathrm{~km}^{2}\right)\end{array}$ & $\begin{array}{l}\text { Soil depth } \\
(\mathrm{cm})\end{array}$ & $\begin{array}{l}\text { Soil } \\
\text { profile }\end{array}$ & $\begin{array}{l}\text { SOC storage } \\
(\mathrm{Pg} \mathrm{C})\end{array}$ & $\begin{array}{l}\text { SOC density } \\
\left(\mathrm{kg} \mathrm{C} \mathrm{m}^{-2}\right)\end{array}$ & Data source & Method & Reference \\
\hline Whole China & 944.86 & $0-100$ & 725 & 185 & 19.05 & & & {$[4]$} \\
\hline
\end{tabular}




\begin{tabular}{|c|c|c|c|c|c|c|c|c|}
\hline Whole China & 915 & $0-100$ & 2500 & 50 & $2.7 \sim 16$ & $\begin{array}{l}\text { Soil species of } \\
\text { China }\end{array}$ & $\mathrm{C}-\mathrm{S}$ & [47] \\
\hline Whole China & 881.81 & $0-100$ & 34411 & 70.31 & 8.01 & The 2nd survey & $\mathrm{C}-\mathrm{S}$ & [48] \\
\hline Whole China & 923.97 & $0-100$ & 2456 & 84.4 & $1.2 \sim 176.5$ & The 2nd survey & $\mathrm{C}-\mathrm{S}$ & [49] \\
\hline Whole China & 923.97 & $0-20$ & 2456 & 27.4 & $0.27 \sim 53.5$ & The 2nd survey & $\mathrm{C}-\mathrm{S}$ & [49] \\
\hline Whole China & 868 veg & $0-20$ & 2440 & 23.81 & 2.67 & The 2nd survey & $\mathrm{C}-\mathrm{V}$ & {$[50]$} \\
\hline Whole China & 868 veg & $0-100$ & 2440 & 69.38 & 8.23 & The 2nd survey & $\mathrm{C}-\mathrm{V}$ & {$[50]$} \\
\hline Whole China & $901.6 \mathrm{cov}$ & $0-100$ & 2473 & 82.5 & $4.65 \sim 17.32$ & The 2nd survey & $\mathrm{C}-\mathrm{L}$ & {$[51]$} \\
\hline Whole China & 928.1 & $0-100$ & 7292 & 89.14 & 9.6 & The 2nd survey & $\mathrm{C}-\mathrm{S}$ & {$[52]$} \\
\hline Whole China & 880.37 & $0-100$ & 3283 & 69.1 & 7.8 & $\begin{array}{l}\text { The 2nd } \\
\text { survey }\end{array}$ & $\mathrm{C}-\mathrm{S}$ & {$[53]$} \\
\hline Whole China & 928.1 & $0-100$ & 7292 & 89.14 & 9.6 & $\begin{array}{l}\text { The 2nd survey } \\
\text { \&observation }\end{array}$ & $\mathrm{C}-\mathrm{S}$ & {$[46,54]$} \\
\hline Whole China & 918 & $0-100$ & 2456 & 83.8 & 9.13 & $\begin{array}{l}\text { The 2nd survey } \\
\& \text { collection }\end{array}$ & $\mathrm{C}-\mathrm{S}$ & {$[45]$} \\
\hline Whole China & 918 & $0-300$ & 2456 & 147.9 & 16.11 & $\begin{array}{l}\text { The } 2 \text { nd survey } \\
\& \text { collection }\end{array}$ & $\mathrm{C}-\mathrm{S}$ & {$[45]$} \\
\hline Whole China & 896 & $0-100$ & 2387 & 102.3 & - & The 2nd survey & $\mathrm{C}-\mathrm{S}$ & {$[55]$} \\
\hline Whole China & 959.63 & - & - & 119.76 & $7 \sim 28$ & $\begin{array}{l}\text { Climate, soil \& } \\
\text { vegetation }\end{array}$ & BIOME3 & {$[6]$} \\
\hline Whole China & 901.14 & - & - & 82.65 & 91.7 & $\begin{array}{l}\text { Climate, soil \& } \\
\text { vegetation }\end{array}$ & CEVSA & [11] \\
\hline Whole China & 925.64 & $0-100$ & & 84.55 & 9.13 & $\begin{array}{l}\text { Published soil } \\
\text { organic carbon } \\
\text { data }\end{array}$ & $\mathrm{C}-\mathrm{S}$ & {$[84]$} \\
\hline Main land of China & 925.45 & $0-100$ & 236 & 100.18 & 10.83 & The 1st survey & $\mathrm{C}-\mathrm{S}$ & {$[56]$} \\
\hline Main land of China & 877.63 & $0-100$ & 2473 & 92.42 & 10.53 & The 2nd survey & $\mathrm{C}-\mathrm{S}$ & {$[57]$} \\
\hline Main land of China & 878 & $0-100$ & 2473 & 92.4 & 10.53 & The 2nd survey & $\mathrm{C}-\mathrm{S}$ & {$[58]$} \\
\hline Main land of China & 870.94 & $0-100$ & 2473 & 89.61 & $2.5 \sim 13.5$ & $\begin{array}{l}\text { The 2nd survey } \\
\text { \& published }\end{array}$ & $\mathrm{C}-\mathrm{S}$ & [59] \\
\hline
\end{tabular}

Table 5. Total carbon storage in Chinese terrestrial ecosystem

\begin{tabular}{|l|c|c|c|c|l|l|l|}
\hline \multirow{2}{*}{ Period } & \multirow{2}{*}{$\begin{array}{c}\text { Biome } \\
\text { Number }\end{array}$} & $\begin{array}{c}\text { Veg_C_Storage } \\
(\text { Pg C })\end{array}$ & $\begin{array}{c}\text { Soil_C_stor } \\
\text { age }\end{array}$ & $\begin{array}{c}\text { Total_C_stor } \\
\text { age }\end{array}$ & Method & \multirow{2}{*}{$\begin{array}{l}\text { Spatial } \\
\text { resolution }\end{array}$} & \multirow{2}{*}{$\begin{array}{l}\text { Referen } \\
\text { ce }\end{array}$} \\
\cline { 1 - 6 } $\begin{array}{l}\text { Last glacial } \\
\text { maximum }\end{array}$ & 7 & 15.5 & 52.4 & 67.9 & Osnabrück model & $0.5^{\circ}$ & {$[5]$} \\
\hline Mid-Holocene & 9 & 70.6 & 112.8 & 183.4 & Osnabrück model & $0.5^{\circ}$ & {$[5]$} \\
\hline Present & 9 & 57.9 & 100 & 157.9 & Data-based estimates & $0.5^{\circ}$ & {$[5]$} \\
\hline Present & 32 & 6.1 & 185.7 & 191.8 & Biogeographical model & - & {$[4]$} \\
\hline $1980 \mathrm{~s}$ & 18 & 57.57 & 118.28 & 175.83 & BIOME3 model & $10^{\prime}$ & {$[10]$} \\
\hline $1980 \mathrm{~s}$ & 37 & 35.23 & 119.76 & 154.99 & $\begin{array}{l}\text { BIOME3 \& Baseline } \\
\text { vegetation }\end{array}$ & - & {$[6]$} \\
\hline $1980 \mathrm{~s}$ & 18 & 53.96 & 117.84 & 171.8 & $\begin{array}{l}\text { BIOME3 \& Baseline } \\
\text { biome }\end{array}$ & $10^{\prime}$ & {$[6]$} \\
\hline $1980 \mathrm{~s}$ & 18 & - & - & 153.43 & BIOME3 model & $10^{\prime}$ & {$[6]$} \\
\hline $1980 \mathrm{~s}$ & 18 & - & - & 158.08 & BIOME3 model & $20^{\prime}$ & {$[6]$} \\
\hline $1980 \mathrm{~s}$ & 18 & - & - & 158.54 & BIOME3 model & $30^{\prime}$ & {$[6]$} \\
\hline
\end{tabular}




\begin{tabular}{|l|l|l|l|l|l|l|l|}
\hline $1981-1998$ & 13 & 13.33 & 82.65 & 95.98 & CEVSA model & $0.5^{\circ}$ & {$[11]$} \\
\hline $2004-2014$ & & 14.60 & 84.55 & 99.15 & Statistics & & {$[84]$} \\
\hline
\end{tabular}

\subsubsection{Total carbon storage in main terrestrial ecosystems}

(1) Total carbon storage in forest ecosystem

Carbon storage in Chinese forest ecosystem was estimated of $28.12 \mathrm{Pg} \mathrm{C}$ (6.2 Pg C in vegetation, $0.89 \mathrm{Pg}$ $\mathrm{C}$ in litter and $21.02 \mathrm{Pg} \mathrm{C}$ in soil) according to detailed data from the Chinese Ministry of Forestry from 1989 to 1993 [30]. With the expansion of forest area, carbon storage in forest ecosystem has increased to 34.08 . Pg C (11.49 Pg C in vegetation, 22.59 Pg C in soil) with forest area of $195.89 \times 10^{4} \mathrm{~km}^{2}$ in the period of 2004-2014 [84].

Chinese forests were a carbon source, with a loss rate of $21 \mathrm{Tg}$ C/a from 1900 to 1949 , but it became a carbon sink with a sequestration rate of $176.7 \mathrm{Tg} \mathrm{C} / \mathrm{a}$ from 1988 to 2001 because forest experienced an expansion [66]. It was forecasted that forests had a net carbon sequestration rate of $97.6 \mathrm{M} \mathrm{t} \mathrm{C/a}$, and approximately $9 \mathrm{Gt} \mathrm{C}$ would be accumulated in forest ecosystems during the period of 1990-2050 [76].

(2) Total carbon storage in grassland ecosystem

There was different grassland area by previous studies, varied between $263.26 \times 10^{4} \mathrm{~km}^{2}$ and $569.9 \times 10^{4}$ $\mathrm{km}^{2}[4,6,21]$. Therefore, the total carbon storage in grassland varied greatly. The total carbon storage in Chinese grassland ecosystem was estimated of $44.09 \mathrm{Pg}$ $\mathrm{C}$ (3.06 Pg C in vegetation and 41.03 Pg C in soil) by a nationwide grassland resource survey in 1991 [34]. The total carbon storage in grassland ecosystem was estimated of $25.69 \mathrm{Pg} \mathrm{C}(1.94 \mathrm{Pg} \mathrm{C}$ in vegetation and $23.75 \mathrm{Pg} \mathrm{C}$ in soil) with grassland area $280.44 \times 10^{4} \mathrm{~km}^{2}$ in 2004-2014 by published soil organic carbon data [84].

In the past 20 years, neither vegetation carbon nor soil carbon in Chinese grassland ecosystem showed a significant change, though human activities could affect its carbon dynamics [36]. Nevertheless, carbon storage in Chinese grassland would increase by $4561.62 \mathrm{Tg} \mathrm{C}$ on conditions that the degraded grassland was recovered. Carbon sequestration would increase by a rate of $9.17 \mathrm{Tg}$ $\mathrm{C} / \mathrm{a}$ if some management practices were adopted, such as lower grazing intensity and enclosure restoration [77].

(3) Total carbon storage in shrub ecosystem

Shrub ecosystems cover an area of $215 \times 10^{4} \mathrm{~km}^{2}$ in China [14]. The total carbon storage in shrub ecosystem varied obviously due to different estimation methods. Carbon storage in shrub ecosystem was estimated of $30.86 \mathrm{Pg} \mathrm{C}$ by baseline vegetation, and $29.34 \mathrm{Pg} \mathrm{C}, 34$ $\mathrm{Pg} \mathrm{C}$ and $34.72 \mathrm{Pg} \mathrm{C}$ as calculated with grids cell of $10^{\prime}$, $20^{\prime}$ and $30^{\prime}$ respectively by the Biome model [6]. The lowest carbon storage was estimated of $7.42 \mathrm{Pg} \mathrm{C}$ with shrub area of $77.69 \times 10^{4} \mathrm{~km}^{2}$ in $2004-2014$ according to published soil organic carbon data [84]. However, it was reported that carbon storage in Chinese shrub ecosystems kept an increase in recent years mainly owing to protection and reforestation policies [13-14].

(4) Total carbon storage in cropland ecosystem

Cultivated cropland covers an area of about $138 \times 10^{4} \sim 130 \times 10^{4} \mathrm{~km}^{2}$ in China $[69,71]$. Carbon storage in cultivated cropland was estimated of $30.55 \mathrm{Pg} \mathrm{C}$ in recent decades by baseline vegetation, 29.84 Pg C, 32.84 $\mathrm{Pg} \mathrm{C}$, and $32.93 \mathrm{Pg} \mathrm{C}$ as calculated with grid cells of $10^{\prime}$, $20^{\prime}$ and $30^{\prime}$ respectively by the Biome model [6]. Carbon storage in cropland was seen increasing markedly in recent half a century because of fertilizer application and improved management practices [40-41], but some cropland experienced carbon loss due to agricultural reclamation [64, 69-70].

(5) Total carbon storage in wetland ecosystem

Wetland ecosystems cover an area about 384510 $\mathrm{km}^{2}$ in China by the National Wetland Resource Inventory conducted in 2004 [42]. Carbon storage in Chinese wetlands was estimated of $8 \sim 10 \mathrm{Pg} \mathrm{C}$ in recent years. The lower estimation in wetland ecosystem was $3.62 \mathrm{Pg} \mathrm{C}$ with wetland area of $14.46 \times 10^{4} \mathrm{~km}^{2}$ in $2004-$ 2014 [84].

Unfortunately, carbon storage in wetland has been decreasing since the $1950 \mathrm{~s}$, with a total loss of approximately $1.5 \mathrm{Pg} \mathrm{C}$ over the last 50 years [42]. However, it is likely that protection and restoration policies will contribute to carbon sequestration by a rate of $30.48 \mathrm{G} \mathrm{g} \mathrm{C/a} \mathrm{[78].}$

Table 6. Carbon storage in different terrestrial ecosystems in China

\begin{tabular}{|c|c|c|}
\hline Ecosystem & $\begin{array}{c}\text { Carbon storage } \\
(\text { Pg C) }\end{array}$ & Reference \\
\hline Forest & 28.12 & {$[30]$} \\
\hline Grassland & $29.1 \sim 44.09$ & {$[34,36]$} \\
\hline Shrubland & $29.34 \sim 34.72$ & {$[6]$} \\
\hline Farmland & $29.84 \sim 32.93$ & {$[6]$} \\
\hline Wetland & $8 \sim 10$ or 3.62 & {$[42,84]$} \\
\hline
\end{tabular}

\section{Discussions}

This paper examined various estimates for vegetation carbon storage, soil carbon storage, the total terrestrial carbon torage in recent years. These estimates have considerable uncertainty due to various data sources and methods, and unstable environments [55, 68].

\subsection{Uncertainty of carbon estimation from data source}

Traditional field investigations are regarded as reliable data source to estimate carbon storage. However, uncertain estimates also exist owing to differences in sampling techniques. Field sampling sites did not always follow the regular proportional spacing, and sample sites were lacking in some regions, such as the Tibetan plateau, desert regions and Taiwan province [36]. 
Two national soil surveys in the 1960s and the 1980s did not include Taiwan. Soil carbon storage in Taiwan was obtained by substitute methods, so the accuracy of estimates of soil carbon storage was likely low [48, 53]. Soil carbon storage in soil profiles beyond $100 \mathrm{~cm}$ was rarely documented at the national level, and a default soil depth of $100 \mathrm{~cm}$ was used in most estimates [45]. In many plains and plateaus, actual soil has a depth more than $100 \mathrm{~cm}$, and the soil below $100 \mathrm{~cm}$ has abundant carbon, therefore soil carbon storage might be underestimated in many plains and plateaus. In many mountainous areas, actual soil depths are less than 100 $\mathrm{cm}[53,79]$, so soil carbon storage might be overestimated.

For vegetation carbon storage, there lacks data of biomass carbon belowground, which was often gained indirectly from the ratio of aboveground biomass to belowground biomass [4, 36]. In most studies, carbon storage in scattered grasslands was ignored, which may have resulted in inaccurate calculation because scattered grasslands distribute widely in China [39]. Carbon storage in protected farmland forest, bamboo forest, and other economical important forest was also ignored [13]. As a result, vegetation carbon storage might be underestimated because of these uncalculated carbon in grasslands and forests. In addition, the definition of forest changed: prior to 1974 , a forest was defined as having canopy coverage of $30 \%$, whereas subsequently a forest was defined as having canopy coverage of $20 \%$ [13]. Thus, the increase of vegetation carbon storage in forest after the 1970s was likely caused partly by changed definition of forest.

\subsection{Uncertainty of carbon estimation from different methods}

Different methods usually led to different results about carbon storage even if the same data source was used. For example, SOC storage of forests calculated by the mean method was consistently higher than that calculated by the median method [80]. To estimate forest carbon storage, various different methods were used, such as the volume-derived method, the age-based volume biomass method, the continuous biomass expansion factor method, the mean biomass density method, the mean ratio method, and biomass regression model [8, 28-29, 32-33]. Therefore, these different methods often lead various estimates on carbon storage.

\subsection{Uncertainty of carbon estimation from unstable environment}

Climate change and anthropogenic activities have led to an unstable environment, which disturbed the geochemical cycle of terrestrial carbon [7]. Climate change significantly affects the rate of carbon accumulation and carbon release [14, 81], and anthropogenic activities cause significant change in carbon storage directly [79, 82-83]. For example, large scale deforestation occurred since the 1950s, which led to an obvious decrease in forest carbon storage; while large scale reforestation occurred since the 1980s, which led to a remarkable increase in forest carbon storage [14, $67,84]$. Thus, climate change and anthropogenic activities have resulted in an unstable environment, which makes it difficult to estimate carbon storage accurately.

\section{Conclusions}

Terrestrial carbon in China mainly exists in forest (28.12 $\mathrm{Pg}$ ), grassland (44.09 Pg), shrub (29.34 34.72 Pg), cropland $(29.84 \sim 32.93 \mathrm{Pg})$ and wetland $(8 \sim 10 \quad \mathrm{Pg})$ ecosystems. Vegetation carbon storage ranged from 6.1 to $57.9 \mathrm{Pg} \mathrm{C}$ based on various estimates. Soil carbon storage in China was estimated of 161.7 185.7 Pg C at a soil depth of $100 \mathrm{~cm}$. Total terrestrial carbon storage was estimated to be $67.9 \sim 191.8 \mathrm{Pg} \mathrm{C}$ in recent decades in China. However, these estimates have considerable uncertainty due to various data sources and methods, and unstable environments. In recent decades, vegetation carbon storage has increased obviously owing to carbon increase in forest, shrub and farmland ecosystems. Soil carbon storage declined owing to intensive land use in some regions, but growth because of fertilizer application and reforestation. The total carbon storage in terrestrial ecosystem increased clearly in recent decades, and it is expected to continue to increase.

\section{ACKNOWLEDGEMENTS}

This study was jointly funded by the National Key Research and Development Program of China (2017YFC0506605), and Jiangsu Natural Science Foundation (BK20170112)

\section{References}

1. B.Tao, Q.S.Ge, K.R.Li, et al. Geographical Research, 20, 564-576. (2001)

2. Q.X.Wang, M.Watanabe, Z.Y.Ouyang, et al. Agr Forest Meteorol, 131,209-224. (2005)

3. S.N.Liu, T.Zhou, L.Y.Wei, et al. Chinese Sci Bull, 57, 1699-1707. (2012)

4. J.Y. Fang, .GH. Liu, S.L. Xu In: R.S. Wang, L. Gao Z.W.Feng (Eds), Hot Spots in Modern Ecology, Beijing: China Science and Technology Press, 251277. (1996)

5. C.H.Peng, M.J.Apps. Tellus, 49, 393-408. (1997)

6. J. Ni Climatic Change, 49, 339-358. (2001)

7. L.Yu, G.Y.Ren. Progress in Geography, 26, 68-79. (2007)

8. X.K.Wang, Z.W.Feng, Z.Y.Ouyang Forest Ecol Manag, 148, 117-123. (2001a)

9. Y.H.Yang, J.Y.Fang, W.H.Ma, et al. Global Change Bio, 16, 3036-3047. (2010)

10. J.Ni. Nord J Bot, 20, 415-426. (2000)

11. K.R.Li, S.Q.Wang, M.K.Cao Sci China Earth Sci, 33, 72-80. (2003) 
12. M.Huang, J.J.Ji, M.K.Cao, et al. Acta Ecol.Sin, 26, 4156-4164. (2006)

13. J.Y.Fang, Z.D.Guo, S.L.Piao. Sci China Earth Sci, 37, 804-812. (2007)

14. S.L.Piao, J.Y.Fang, P Ciais, et al. Nature, 458, 1009-1014. (2009)

15. S.L.Piao, J.Y.Fang, Q.H.Guo. Acta Phytoecologica Sinica, 25, 603-608. (2001a)

16. W.Q.Zhu, Y.Z.Pan, J.S.Zhang. J Plant Ecol, 31, 413-424. (2007)

17. G.D.Sun. Climatic and Environmental Research, 14, 341-351. (2009)

18. H.N.Kang, Q.Y.Ma, J.Z.Yuan. Chinese Journal of Applied Ecology, 7, 230-234. (1996)

19. G.H.Liu, B.J.Fu, J.Y. Fang. Acta Ecol.Sin, 20, 733741. (2000)

20. J.Shi, L.L.Cui. Landscape Urban Plan, 98, 75-85. (2010)

21. Q.B.Wu, X.K.Wang, X.N.Duan, et al. Acta Ecol.Sin, 28, 517-525. (2008)

22. C.X.Zhang, G.D.Xie, L. Zhen, et al. J Appl Ecol, 2, 315-321. (2011)

23. B.Xu, Z.D.Guo, S.L.Piao, et al. Sci China Life Sci, 53, 776-783. (2010)

24. J.Y. Fang, A.P.Chen. Acta Bot Sin, 43, 967-973. (2001)

25. Y.D.Pan, T.X.Luo, R.Birdsey, et.al. Climatic change, 67, 211-236(2004)

26. X.L.Xu, M.K.Cao, K.R.Li. Climatic Change, 26, 110. (2007)

27. J.Y.Fang, G.G.Wang, G.H.Liu, S.L.Xu. Ecol Appl, 8, 1084-1091(1998)

28. J.Wang, Y.Q.Chen, X.M.Shao, et al. Land Use Policy, 29, 737-749. (2012)

29. Z.D.Guo, J.Y.Fang, Y.D.Pan, et al. Land Use Policy, 259, 1225-1231. (2010)

30. Y.R.Zhou, Z.L.Yu, S.D.Zhao. Acta Phyoecologica Sinica, 24, 518-522. (2000)

31. M.Zhao, G.S.Zhou. Scientia Geographica Sinica, 24, 50-55. (2004)

32. M. Zhao, G.S Zhou. Climatic Change, 74, 175-189. (2006)

33. H.K.Li, Y.C.Lei, E.S.Zeng. Scientia Silvae Sinicae, 47, 7-13. (2011)

34. J. Ni.Arid Environ, 50, 205-218. (2002)

35. S.L.Piao, J.Y.Fang, L.M.Zhou, et al. Global Biogeoc hem Cy, 20, 1-10. (2007)

36. J.Y.Fang, Y.H.Yang, W.H.Ma, et al. Sci China Life Sci, 40, 566-576. (2010)

37. C.M. Fang. Sci China Life Sci, 54, 490-492. (2011)

38. S.L.Piao, J.Y.Fang, J.S.He, Acta Phytoecologica Sinica, 28, 491-498. (2004)

39. J.W.Fan, H.P.Zhong,W.Harris. Climatic Change ,86, 375-396. (2008)
40. Y.Huang, W.Zhang, W.J.Sun, et al. Ecol Appl, 17, 692-701(2007).

41. G.X.Pan, X.W.Xu, P.Smith, et al. Ecosystems and Environment, 136, 133-138. (2010)

42. X.H.Zhang, D.Y.Li, G.X.Pan, et al. Advances in Climate Change Research, 4, 202-208. (2008)

43. W.X. Kang, H. Tian, J.N. He, et al. J soil Water Conserv, 23, 129-134. (2009)

44. P.Gong, Z.Niu, X.Cheng, et al. Sci China Earth Sci, 53, 1-7. (2010)

45. Z.P.Li, F.X.Han, Y.Su, et al. Geoderma, 138, 119126. (2007)

46. D.S.Yu, X.Z.Shi, H.J.Wang, et al. J Environ Manage, 85, 680-689. (2007b)

47. G.X.Pan. Bulletin of Science and Technology, 15, 330-333. (1999)

48. H.B.Wu, Z.T.Guo, C.H.Peng. Global Biogeochem cy, 17,: 1048-1058. (2003)

49. X.L.Xie, B.Sun, H.Z.Zhou, et al. Acta Pedologica Sinica, 41, 35-43. (2004a)

50. X.L.Xie, B.Sun, H.Z.Zhou, et al. Acta Pedologica Sinica, 41, 687-698. (2004b)

51. S. Wang, M.Huang, X.Shao, et al. Environ Manage, 33, 200-209. (2004)

52. D.S.Yu, X.Z.Shi, W.X.Sun, et al. Chinese Journal of Applied Ecology, 16, 2279-2283. (2005)

53. Y.H.Yang, A.Mohammat, J.M.Feng, et al. Biogeochemistry , 84, 131-141. (2007)

54. D.S.Yu, X.Z.Shi, H.J.Wang. Pedosphere, 17,11-18. (2007a)

55. E.Liang, D.X.Cai, D.C.Zhang, et al. Chinese Soil and Fertilizer, 6, 75-80. (2010)

56. S.Q.Wang, C.H.Zhou. Geographical Research, 18, 349-357. (1999)

57. S.Q.Wang, C.H.Zhou, K. R.Li, et al. Acta Geol SinEngl, 55, 533-545. (2000)

58. C.H.Zhou, Q.M.Zhou, S.Q.Wang.Ambio, 32, 6-12. (2003)

59. Z.B.Xie, J.G.Zhu, G.Liu, et al. Global Change Biol, 13, 1989-2007. (2007)

60. N.Mi, S.Q.Wang, J.Y.Liu, et al. Global Change Biol, 14, 2380-2387 (2008).

61. P.H.Lindert, J.Lu, W.Wu. Soil Sci, 161, 329-342. (1996)

62. G.X.Pan, L.Q.Li, X.H.Zhang, et al. Advance in Earth Sciences, 18, 609-619. (2003)

63. J.Y.Liu, S.Q.Wang, J.M.Chen, et al. Acta Geol SinEngl, 59, 483-496. (2004)

64. H.B.Wu, Z.T.Guo, Q.Gao, et al. Agr Ecosyst Environ, 129, 413-421. (2009)

65. R. Lal. Land Degrad Dev, 13,469-478. (2002)

66. S.Wang, J.M.Chen, W.M.Ju, et al. J Environ Manage, 85, 524-537. (2007)

67. L.Huang, J.Y.Liu, Q.Q.Shao, et al. J Renew Sustain Ener, 16, 1291-1299. (2012) 
68. G.R.Yu, X.R.Li, Q.F.Wang, et al. J Resour.Ecol, 1, 97-109. (2010)

69. G.H.Song, L.Q.Li, G.X.Pan, et al. Biogeochemistry, 74, 47-62. (2005)

70. C.S.Li. Quaternary Sci Rev, 20, 345-350. (2000)

71. Y.Q.Yu, Y.Huang, W.Zhang. Global Planet Change, 83: 115-128. (2012)

72. S.An, H.Li, B.Guan, et al. AMBIO, 36, 335-342. (2007)

73. Y.Huang, W.J.Sun, W.Zhang, et al. Glob Change Biol, 16, 680-695. (2010).

74. Y.Huang, W.J.Sun, W.Zhang, et al. Sci China Life Sci, 40, 577-586. (2010)

75. Y.G.Wang, Y.Li, X.H.Ye, et al. Sci Total Environ, 408, 1925-1931. (2010)

76. X.Q.Zhang, D.Y.Xu. Environ Sci Policy,6, 421-432. (2003)

77. R.Guo, X.K.Wang, F.Lu. Acta Ecol.Sin, 28, 862868. (2008)

78. X.N.Duan, X.K.Wang, F.Lu, et al. Acta Ecol.Sin, 28, 463-470. (2008)

79. J.F.Zheng, K.Cheng, G.X.Pan, et al. Chinese Sci Bull, 56, 3748-3758. (2011)

80. Y.C.Zhao, X.Z.Shi, D.C.Weindorf, et al. Soil Sci Soc Am J,70,1378-1386 (2006)

81. C.H.Peng, X.L.Zhou, S.Q.Zhao, et al. Global Planet Change, 66, 179-194 (2009)

82. Z.C.Cai. Water Air Soil Poll, 91, 383-393 (1996)

83. D.Zhou, P.An, Z.Pan, et al. J Agr Sci-Cambridge, 150, 179-190. (2012)

84. L.Xu, G.R.Yu, N.P.He, et al. Sci Rep-Uk,8,2806. (2018) 